\title{
Crisis events and the inter-scalar politics of humor
}

Juha Ridanpää (Geography Research Unit, University of Oulu)

\begin{abstract}
Although humor is generally associated with innocent amusement, in the case of crisis events it has various psychological, social and politically charged effects, both negative and positive. In times of crisis humor functions as a technique for neutralizing emotionally charged areas and by that means provides hope. On the other hand, in contemporary society there exist sensitive socially restricted and culturally dependent boundaries beyond which humor is not permitted to extend. This article discusses how humor becomes politicized when it functions as a part of crisis events, both as a trigger for crises and as a strategic tool to manage them. Specific attention is paid to the impact of spatiality by dissecting how the links between crisis and humor change when the scalar perspective shifts and how different spatial levels interact when humor becomes political. 'Body', 'local', 'regional', 'national' and 'global' are important spatial abstractions across which the socio-political meanings connecting humor and crisis events become produced.
\end{abstract}

Ridanpää, J. (2019). Crisis events and the inter-scalar politics of humor. GeoJournal, 84(4), 901-915.

\section{Introduction}

Crisis is a concept with numerous definitions and the word itself is often connected to various social, political, economic and also mundane phenomena (e.g. Clark 1988; Halpern 1973; Weaver 2017). By its common definition, the concept of crisis refers to a time of intense difficulty or danger, with a certain level of dissipation of social order. A crisis is an event during which the normal rhythm of (social, political, economic, psychological, everyday) life is halted. Although crisis has long been an all-pervasive rhetorical metaphor and 'crisis-talk' has spread everywhere, it is an accepted axiom that only subjects can be involved in crisis (Holton 1987). Although it is often the case that the origins of a crisis can be traced to repressive state structures (see Solomos et al 1982), there also exist various forms of crises that have their origins beyond human activity, such as natural disasters, or 
crises which are only partly caused by human activity, such as economic crises. In the case of psychological or health-related crises the impact of human action is often difficult to estimate. In this article crisis is approached as a socio-political condition, or event, that becomes constituted and 'materialized' in different manners across various spatial scales.

The notion of crisis entails a certain sense of seriousness, or to be more precise, seriousness is an elementary aspect of crisis. Correspondingly, humor is commonly associated with amusement, and, partly mistakenly, is considered an antidote to seriousness. However, humor has several social, political, cultural and economic functions which, in most cases, are not acknowledged due to its common associations with lightheartedness, innocent amusement and entertainment (see Billig 2005; Dodds and Kirby 2013; Kuipers 2008; Lockyer and Pickering 2008). There exist varied, often opposing, opinions about the suitability of using humor in the context of events of crisis. While for some people laughing during an event of crisis crosses the barrier of good taste, for others laughter has a useful therapeutic effect. Humor can be a politically charged institution in several ways: Notably, it reflects contemporary sociopolitical worldviews but also is a sociopolitical worldview in itself. Humor also functions as a form and forum of social criticism and at its best/worst can be utilized as a weapon against dominant authorities during a time of crisis. Humor can serve as a tool for political aggression, but also as an asset for emancipatory purposes (Ridanpää 2010).

This article discusses how humor becomes politicized when it becomes part of a crisis event, both as a trigger for a crisis and as a strategic tool to manage one. The article pays particular attention to the impact of spatiality by dissecting how the links of crisis and humor attain their various meanings through the inter-scalarity of sociopolitical processes. Crisis events have a major function with respect to the politics of the body, as well as the construction of local community identities, regionalism, nationality, nationalism, internationality and internationalism. In this article, the inter-scalar nature of politically serious crises and their connection to humor is discussed by using the following examples: 
(1) Body: Sexist jokes

(2) Local: School shootings

(3) Regional: Sámi people as an othered ethnic minority

(4) National: 9/11 terrorist attacks

(5) Global: Mohammed cartoon controversy

Crisis events and the politics of humor take place on various spatial scales, but the key argument here is that when an event turns into a crisis, regardless of its particular location or scale, it nevertheless has simultaneously both origins in and impacts on other spatial scales as well. It can also be argued that crisis events and the politics of humor construct inter-scalarity. Through the media, local crises may turn into national and sometimes international concerns, while this 'scalar shift' can also be a factor increasing the emotional load of the crisis event. In human geography conceiving scale as an unproblematic, pregiven and fixed hierarchy of bounded spaces, a level of analysis, has been challenged for a long time (see Delaney and Leitner 1997). During recent years, the theoretical debate has leaned more and more on Henri Lefebvre's theorizations about the production of space (Lefebvre 1991), while at the same time the argument that scale is a social construction has gained momentum (Marston 2000). The idea of scale as an ontologically given category has been rejected in constructionist framings, according to Marston. She argues that in social theoretical studies 'the fundamental point being made is that scale is not necessarily a preordained hierarchical framework for ordering the world - local, regional, national and global. It is instead a contingent outcome of the tensions that exist between structural forces and the practices of human agents' (p. 220).

Although human geographers have also questioned the usefulness of the concept of scale and have even proposed to abandon it completely (see Marston, Jones and Woodward 2005), 'body', 'local', 'regional', 'national' and 'global' are important spatial abstractions across which the socio-political meanings connecting humor and crisis events become produced. According to Escobar (2007), the theory of 'geography without scale' ontologically refers to complex, emergent spatial relations, self-organization and ontogenesis. At the same time 'geography without scale' ignores the hierarchal and vertical aspects of social space, standing as a theoretical viewpoint that Escobar himself 
deems 'flat alternative'. Correspondingly, Jonas (2006) brings up how rejecting the concept of scale altogether would lead to ignorance when thinking about and acting upon contemporary economic, political, social and environmental change. Jonas asserts that human geographers should recognize that scalar concepts are fundamental to the organizing and presentation of human-geographical narratives; that they should pay less attention to an epistemology of scalarities such as local-to-global and focus instead on the 'inbetweenness' of scale; and also that human geographers should work with, not around or outside, particular scalar categories. Events connected to a particular scale become meaningful when they are perceived and imagined through alternative scales, along with the opportunities and obstacles they pose (see Howes 2000). Although this paper is arranged by scalar order (body, local, regional, national, global), each case discussed exemplifies how crisis and humor attain their sociopolitical meanings through the interaction between different scales.

\section{Body, crisis and sexist humor}

The idea of perceiving the human body as a spatial scale was first introduced by feminist geographers (e.g. Rose 1993), after which the number of studies focusing on the embodied nature of socio-political/spatial events has increased remarkably. Although 'body' is a scale of its own,

bodily experiences often attain their meanings at the local scale, within particular local contexts, such as home/household (Marston 2000; Dyck 2005). This can be formulated also so that the scale of body is reproduced within households and local communities (Gough 2010, p. 133). This touches also Marston's (2000) conceptualization of the household as a geographical scale, how 'the role of the home/household is central to understanding the social construction of space-place tensions' (p. 238). Although Marston offers an insightful reconceptualization of feminist-Marxist research on domesticity, her argument has been criticized for approaching domesticity, not as an actual geographical scale, but instead as a socio-spatial arena (Brenner 2001, pp. 596-598). In phenomenological geography it has been particularly underscored, partly in critique of the feminist approaches, that 'it is in the scaled processes of embodiment and emplacement that relations of difference, otherness and identity construct meaning, relationship and human possibility' (Howitt 2002, p. 311). 
During recent years among sociopolitical studies of humor there has prevailed a discourse or claim specially underscoring that 'humor is serious' by its very nature (Ridanpää 2014a; 2014b).

No matter how innocent and harmless some jokes may feel, their inner logic is often rooted in subordinating power relations. This becomes evident in sexist humor, a mechanism that conveys the subordinate position of women, and may also support violence against women (Bemiller and Schneider 2010). Studies scrutinizing how sexist joking is associated with rape proclivity illustrate how serious a matter sexist humor is. In these studies it has been found that whereas sexist jokes may enhance male in-group cohesion, at the same time such joking not only serves as a form of sexual harassment but also amplifies self-reported rape proclivity and victim blame (Thomae and Pina 2015).

The manner of how humor becomes embodied contains the fundamental question of whether it functions affirmatively or destructively. In her classic work Irony's edge (1994) Linda Hutcheon argues that 'The position that irony works in a positive and constructively affirmative way is usually held by those who also see irony as a powerful tool or even weapon in the fight against a dominant authority - which irony is said to work to destroy' (p. 27). Feminist, post-colonial, and gay and lesbian theorists of humor have often embraced this argument. Although sexist jokes are not embodied acts (of crime) as such, their negative effects are in several ways linked to how women experience their bodily being, which is linked to how people conceive of themselves as human beings. Sexist humor is a form of rape in several different ways. In sexist jokes the laughter is directed at the female body and the impact is an emotion of being objectified but also a concrete bodily feeling of repugnance to one's own body, a feeling of being violated. Another, simultaneously affirmative and destructive aspect of sexist joking is when it is employed by women as a defense mechanism. In her study on inequality in breast cancer support groups, Clark (2017) notes how the women engage in sexualized joking 'to cope with the embarrassment, shame, and self-doubt resulting from changes to their bodies' (2017, p. 27). 
In crisis situations humorous interventions can have both positive and negative effects. Positive effects of humorous interventions consist of, for example, impasse breaking, conflict reframing, freeing/empowering, and humanization of the situation. Alternatively, humorous interventions may also have negative impacts such as lack of desired effect, increased negative affect, confusing the situation, and perceiving the humor as demeaning. The biggest challenge to the use of humor in crisis situations, for instance as a therapeutic tool, is the victims or clients not understanding the joke, which at its worst would mean that the victims would consider themselves to be the target of an insult (Pollio 1995). The question about whether the intended audience shares a similar disposition with the target of the humor is therefore a crucial one (see Purcell, Brown and Gokmen 2009). As has been discussed in studies of (politically) sensitive issues, it is actually highly typical that different people understand humor in completely different, even opposite manners (Ridanpää 2014a).

The implications of sexist joking take place not only at bodily or domestic scales, but also on an institutional level, which is seen for example in how menstruating has been used as the logic behind excluding women from leadership positions in working life. Humor based on the sexual objectification of women supports the notion that some forms of woman abuse are acceptable (Bemiller and Schneider 2010, p. 476). In corresponding manner, in the Finnish Border Guard (FBG) service the role of women turned into a topic of wider debate when an elder border guard publicly claimed in a TV broadcast in 2002 that menstrual periods prevent female border guards from performing their duties properly (Prokkola and Ridanpää 2015, p. 1383). According to this logic, border guarding, as a central profession connected to international crisis management, is not a suitable job for women because of their bodily features. In our modern world such an argument may sound outrageous, but also (in an ironic manner) humorous and it can make men as well as women laugh. This nevertheless does not take anything away from how serious a matter sexist speech is. Although there is substantial variation between different countries concerning to what extent sexist speech is permitted or condemned, for women around the world sexism is still a recurrent part of everyday life, manifesting itself most typically in domestic expectations connected with femininity (Bemiller and Schneider 2010). Irrespective of how substantially the general attitudes towards sexual equality have 
changed along with feminist criticism, the world is still first and foremost a masculinist space. Sexist jokes and sexist speech in general may be condemned, but at the same time is still considered intelligible, something with a sensible logic.

Although sexist joking is a source of crisis that happens first and foremost as an individual bodily experience, the discourse of sexism is also maintained through the global scale. Through the global media, the sexist comments of political leaders such as Silvio Berlusconi and Donald Trump inflict poisonous bodily experiences across the world. This is also connected to the wider discussion concerning the limits of acceptable speech. In contemporary society the boundary between when sexist joking is considered 'acceptable behavior' or sexual harassment is fluid, and the sexist harasser can therefore always defend himself with the claim that 'he did not mean it that way' (Kotthoff 2006, p. 17). It has been argued that 'only joking' is a typical rhetorical device upon which offensive comic discourse relies (Lockyer and Pickering 2008, p. 812). Sexist humor has a long history, but nowadays it is more open to criticism than before, and in fact, by using sexist humor, controversial politicians such as Berlusconi and Trump have lost part of their political credibility and turned into targets of laughter themselves.

\section{The local scale, communities and school shooting humor}

As underscored in this paper, sociocultural events that take place at various scales are continuously and simultaneously reproduced through other scales. From the viewpoint of inter-scalarity, or scalar interaction, the local scale plays a particular role. In fact, as Paasi (2004, p. 539) has argued, in cultural geography the 'local' scale has been key to understanding the politics of place as inter-scalar. Correspondingly, approaching local as a binary to global (as in the familiar phrase 'from local-to-global') has been popular in various subfields of geographical studies (see Jonas 2006). When perceived from a relational point of view, everyday activities such as care work are plainly not local matters, but rather inter-scalar effects of the stretching of sociopolitical relations over space, constructed and negotiated at interlocking scales of bodies, homes, cities, regions, nations and the global (Dyck 2005). Leaning on Michael Billig's (1995) theory of 'banal nationalism', it has also been argued that the local scale functions to define nations and national 
identities, particularly in the case of the United States (Appleton 2002). With a corresponding approach Jones and Desforges (2003) have analyzed - by drawing on evidence from focus groups of students from the University of Wales - how senses of nationalism are locally reproduced, concluding with an argument that nationalism is 'a process of mutual mediation between messages that are produced at all spatial scales' ( $p$. 290).

Compared to place, the local scale is often associated with socially shared bonds between people, a community. The local scale refers thus to a geographical, sociological and psychological space defined by face-to-face experiences and group cohesion (Appleton 2002, p. 422). In inter-disciplinary studies of humor it has been emphasized how humor is linked to group cohesion. People use humor, both as a standpoint and as a rhetoric device, in the process of organizing, representing and reasoning their personal experiences, as well as in perceiving their identities in relation to others. Humor thus functions as a mechanism through which group affiliation and identities become established (Kuipers 2009; Terrion and Ashforth 2002). Humor possesses a shared social purpose that facilitates group cohesion and social bonding, as well as creation and preservation of group identities (Palmer 1993; Davies 1990), especially in daily interaction (Norrick and Chiaro 2009).

Local-scale crisis events may contest group affiliation; they may also be spread across the globe by the media and be followed intensively. School shootings are a tragic but illustrative example of such crises. The interaction between the media, the public, and politicians has a unique role in terms of how school shootings - a form of breakdown in social order - spread moral panic (Burns and Crawford 1999). Although each local school shooting is mourned across the world through the media, the emotional impact of the crisis is strongest at the local level. Oksanen et al write (2010), 'as a form of social disaster, school shootings are very problematic for community life and not easy to cope with. This is because the offenders themselves are usually members of the community, and because the roots of the violence emerge from within the community. This might cause not only grief, but also fear, insecurity and collective guilt among the inhabitants of the communities' (p. 23). 
A school shooting is an extremely serious and sensitive topic, and any joke touching on it usually causes fierce reactions, condemnations and even further security measures. A recent example of this concerns the Parkland School shooting - a mass shooting with 17 killed and 17 wounded victims at Marjory Stoneman Douglas High School (MSD) in Parkland, Florida, in February 2018. Following the incident, Utah schools received at least nine threats for more shootings in less than a week, which none of which was made seriously. For example, as a joke, a 13-year-old boy from Thomas Jefferson Junior High School in Kearns made a post on social media threatening violence at his middle school. Although the boy considered the message to be 'just funny', he was arrested for making a terroristic threat (see Reavy 2018).

A striking feature following the Parkland School shooting was that in social media a collective discussion about the topic was carried out through memes. Some of the memes were sympathetic, some more critical, some used irony for social criticism, while others just made fun of the shooting. Although the use of memes in social media does not automatically link to humor, an Internet meme usually is, as Patrick Davison (2012) defines it, 'a piece of culture, typically a joke, which gains influence through online transmission' (p. 122). The Parkland School shooting episode quickly turned into a wider discussion about the gun laws of the United States. Fierce debate arouse after President Donald Trump tweeted: 'If schools are mandated to be gun free zones, violence and danger are given an open invitation to enter' (...) 'almost all school shootings are in gun free zones. Cowards will only go where there is no deterrent!' Trump's comments were fiercely criticized and in social media a major part of that criticism was expressed in the form of humorous memes. For example, one meme showed an image of Trump sitting in McDonalds with a cup of Coca Cola and a text: 'I don't always play golf and pig out in McDonalds. But when I do I make sure it's while 17 children killed in a mass shooting aren't even buried yet.' Another meme, referring to Trump's earlier tweets, presented an image introducing, in ironic manner, a collection of different types of guns for different teachers ancient ones for history teachers and so on. 
The memes functioned as a forum for social criticism, but communicating such serious matters as school shootings through memes was also criticized, for example by Kory Grow (2017) in Rolling Stone in an essay titled: 'Stop Making Mass Murder a Meme: "Thoughts and prayers" aren't enough - but sarcastic and outraged reactions to them aren't much better'. Unsurprisingly, humorous memes attaching political sarcasm and local tragedies easily become objects of heavy criticism, especially when wider publicity is gained. When Attitude magazine tweeted a meme containing a picture of the front cover of the magazine, showing a muscular man with the text 'Just to be clear @realDonaldTrump these are the only guns you should see in a classroom...', the result was a torrent of fierce comments from the readers. After fierce reactions the tweet was deleted and the editors and spokespersons of the magazine apologized with excuses such as how the joke had been tweeted by a junior member of staff and that the tweet 'is certainly not reflective of wider editorial policy' (Beresford 2018).

As the case of the Attitude tweet illustrates, during events of crisis social media plays a crucial role in several ways. In their study focused on the effectiveness of humorously framed crisis response messages on social media, Xiao, Cauberghe and Hudders (2017) have found that in cases of unknown or ambiguous crises, humor works by minimizing stakeholders' perception of the severity of the threat. Correspondingly, in their study of how audiences seek out crisis information, Austin, Fisher Liu and Jin (2012) explain how during a case of crisis humor appears as a motivational reason to use social media as a communication forum. In that same study it was also emphasized that, although various forms of social media contain plenty of humorous material, social media also contains a great deal of extremely serious content, which makes its use less appealing.

It is perhaps somewhat troublesome that a tragedy such as the Parkland School shooting offered an opportunity to not only criticize, but also 'just make fun' of political leaders. In part through politically charged memes, the topic of discussion was transferred away from the local level into new spatial contexts and scales. The discussion in the media shifted to topics touching American national politics as well as wider global discussions about security, with a 'speed of transmission' that 'is no longer limited by the movement of individuals', as Davison (2012, p. 122) describes the basic nature of social media. On the 
other hand, school shootings stand as tragic episodes which may turn the wider national interest to the social life of small communities, both in good and bad ways.

The intensive media activity following school shooting episodes has a major impact on how small communities are perceived by outsiders, and on how community members perceive themselves, but also influences national reputations. Six students and two staff members were killed in a school shooting in November 2007 in the small town of Jokela, Finland. Oksanen et al (2010) interestingly found that after the incident many locals felt guilty for being a local, for being from Jokela (p. 22). Ten months later another school shooting incident took place in Finland, in Kauhajoki, a small town located deep in the Finnish countryside, with nine fellow students and a teacher killed. In both Finnish cases the main reaction of the local inhabitants was 'this can't happen here', since the public image of school shooting events is connected to America and the dark sides of American society. Another example of how local crisis events can be subsumed into the image of the nation is the terrorist attacks in Oslo and on the island of Utøya, Norway, perpetrated by Anders Behring Breivik, which resulted in 77 deaths. The whole episode is generally referred to as 'the 2011 Norway attacks,' which exemplifies how a local crisis can turn into a national disaster and even into a symbolic marker for the nation. The case also exemplified the affirmative role of contemporary social media: It has been studied how Twitter worked as a channel through which sharing emotions and re-establishing national solidarity became possible after the attacks (Eriksson 2016).

\section{Imaginative regions and ethnic humor}

There are several alternative manners of comprehending region as a scale. Usually regions are conceived of as functioning as national/cross-national institutional units that operate in a linked manner under national administrative systems. During recent years the discussion has mainly focused on whether regions should be understood as fixed or relational spatial units. In the case of regions, relationality refers to the idea that spatial identities do not construct, happen or take place in specific, fixed cartographical locations but rather come into existence on the level of interactions between various actors and cultural and social institutions (see Jones 2009; Paasi and Metzger 2017). Correspondingly, 
regions can be approached as sociocultural constructions of 'imaginative geography', a term used by Edward Said in his classic work Orientalism (1978). Said's main argument concerns how the Orient, as an imaginative region, exists only by courtesy of Western power to imagine the history of the Eastern world to fulfil its own imperialist needs. Orientalism is a process in which fictiveness, reality, artificiality and the representativeness of space interconnect through the cultural, political and scientific creativeness of the human mind, a process in which stereotypes and myths find their spatial manifestations.

To illustrate how humor and crisis become interconnected th the regional level, I use the example of ethnic humor, in this case the humor utilizing the stereotypes of Sámi minorities. The Sámi are the only indigenous people of the European Union and are a minority living in four different countries: Norway, Sweden, Finland and Russia. Depending on estimations, their numbers vary between 50000 and 100 000, of which approximately 10000 live in Finland. Generally, ethnic stereotypes are regenerated in humor used in the media and in everyday joking, and at the same time, the wider institution of social othering is maintained (Perks 2010). The Sámi people have played a central role in terms of how regional inequality in Finland has been established and maintained by myths and stereotypes. The North of Finland, 'nature Finland', is an imaginative region which over the course of several centuries has been constituted through various forms of stereotyping, mystifying, exoticizing and othering of Sámi minorities in accordance with the nationalist endeavors of southern Finland (see Ridanpää 2016).

For centuries the Sámi people of Finland have been an 'internal other' (Sidaway 2000; Johnson and Coleman 2012), an ethnic group written out of Finland's grand national narrative. At the end of the $19^{\text {th }}$ century, Finland was striving for independence while at the same time when in the wider European race discussions Finns were perceived as a Mongoloid race, a pseudo-theory based on earlier ethno- and anthropological descriptions of Sámi people (Tuulentie 2001, pp. 82-84). Therefore for nationalist purposes the Sámi were given the role of marking the distinction between civilization and primitiveness, representing a counterpart in the discourses of Finnish ethnic nationalism.Although it has been argued that perceiving the Sámi people solely as the objects of colonialist oppression is somewhat overly simplifying (see Lehtola 2012), there is 
nevertheless a long history of internal colonialism, especially forced Christianization, after which Sámi minorities have been obliged to live under a state of crisis, generation after generation. In the travelogues of the $18^{\text {th }}$ century the Sámi people were commonly described within the context of stereotypes that revolved around the cold, barren northern nature and also in terms of stereotypes about drunkenness and heathenism (Virkkula 2000, pp. 248-249; cf. Lehtola 1997, pp. 67-68). It is naturally a matter of opinion whether ethnic oppression should be conceived as a state of crisis or rather as a permanent state of social inequality. In this paper I understand the social process of ethnic othering as a historical continuum of crisis attacks, a state of oppression under which ethnic minorities have been forced to live and cope with generation after generation.

Along with exoticism and mystification, there are several other examples of how Sámi stereotypes have been used to insult and mock. At a local level there is a long history of selling playing cards for tourists, with 'humorous' caricatures of drunk and dirty Sámi men (see Nuorgam and Karhu 2010, p. 179). Louder debate concerning the insulting nature of Sámi representations arose in the late 1980s after a Finnish comedy TV show Hymyhuulet presented sketches of two completely drunk and dirty Sámi men, Naima-Aslak (PirkkaPekka Petelius) and Soikiapää (Aake Kalliala), who became known for their punchline 'nunnuka-nunnuka-lai-lai-laa-laa', a mocking imitation of traditional Sámi yoik singing. The sketches utilized Sámi stereotypes in various manners and had the result that, for the first time, the Sámi people publicly voiced criticism against how they and their cultural heritage were presented in the media. This caused wider discussion concerning how ethnic minorities should be represented, but it did not end the joking: Another comedy TV show, Viemäri $T V$, parodied not only Sámi people, but especially their criticism of Sámi stereotypes - one skit featured a group of angry Sámi men wandering around Helsinki with automatic rifles, trying to find 'those nunnuka-nunnuka clowns'.

Following the Sámi criticism the public discussion touching ethnic minorities has become more sensitive, but opinions are still marked by dissention. Selling the above-mentioned Sámi playing cards to tourists was banned, but in practice this meant that they were sold under the table, at a higher price. It needs to be remembered that the discussion over racist representations does not have a similar history in Finland as in many other western 
countries. For example, a major Finnish candy company Brunberg were as late as in 2001 selling chocolate-coated marshmallow treats called 'Neekerinsuukko', 'Negro kisses'. It took a long period of globalization before the use of such terms was considered racist and there is still much sentiment amongst Finns that representing the Sámi people through stereotypes is neutral. This also illustrates how there are differences between countries in terms of how 'ironic attacks' are received and responded to. The Sámi theme became topical yet again when the Finnish rap artist Uniikki published a music video 'Nunnuka-lailaa' in 2015, which along with several stereotypes attached to northernness, uses the 'classic' yoik singing parody from the 1980s in the chorus of the song. Uniikki fans reacted immediately with comments in his Instagram account such as: 'This nunnuka stuff is not funny at all', 'you should educate yourself a little bit about Sámi affairs', 'completely stupid racism', 'did it occur to you that some of your fans might be Sámi?', and 'it's really annoying that this sort of "nunnukalailaa" yelling is heard even today. Insulting and stereotype-confirming especially for the younger audiences'.

Uniikki responded to the criticism by arguing that 'the song and the video is just about praising the Lapland flair. It has nothing to do with the old Sámi sketches'. Uniikki comes from Helsinki, the capital of Finland, which adds its own dimension to this discussion. Correspondingly, Märät säpikkäät, another comedy TV show, which was shown between 2012 and 2013, consisted solely of jokes using old Sámi stereotypes in a vulgar manner. However, Märät säpikkäät was not condemned, but rather praised, since the leading actors of the show were Sámi people themselves. This raises several questions concerning the relationship of ethnic humor and otherness: Does one's belonging to an ethnic group justify stereotypes directed at the whole community? Who owns ethnic heritage? Are stereotypes deconstructed or just kept alive by self-consciously ironic stereotyping? These questions are connected to wider discussions about identities and belonging. From the viewpoint of regionality it is not relevant how racist humor is directed at people living in a particular region, but rather how laughter directed at ethnic minorities constitutes regional stereotypes, which in the case of Finland have been exploited for nation building. Humor directed at ethnic minorities is also universal, a shared global discourse of its own, which attains several forms and varieties all over the world. 


\section{Nation, nationalism and 9/11 humor}

Although the world as a system of nations has a relatively short history, today the social and political role of the scale of nation and nationalism is remarkable. Nation is 'so central, and protean, a category of modern political and cultural thought, discourse, and practice that it is hard indeed to imagine a world without nationalism' (Brubaker 1996, p. 10).

Nationalism is not a process or a discourse that is entirely tied to the scale of national, but rather it is produced simultaneously in the spatial scales of global, national, regional, local, domestic and personal (Jones and Desforges 2003). In similar manner as regional identities are constructed in relation to the 'others', a categorical distinction from the 'other' is an important part of how national identities become constructed. In the case of America over the course of history there have been several 'others' against which the nationality, 'being American', has been established. It is highly typical that national self-images are reflected against neighboring countries, and in the case of America both Mexico and Canada have had the role of 'other' in particular socio-cultural contexts. During the Cold War, American values were defined as a categorical opposition to the Soviet society, while today (an abstraction of) the Islamic world represents the counterpart for American people. In the following it is discussed, using the example of the 9/11 terrorist attacks, how humor and crisis are connected to nationalism and wider sociocultural processes of state construction.

Although 'American Orientalism', for example in form of neocolonialist oil trade relationships, has a much longer history (see Little 2002), after the terrorist attacks in Manhattan on September 11, 2001, it became clear to all the American people why the Islamic world should be seen as the 'other'. The attacks were a national disaster and an impetus for President George W. Bush to declare the Global War on Terrorism. The attacks also ushered in a new form of insecurity, the shared feeling that America, as a nation, was under threat. According to Dittmer (2005) 'the attacks of 9/11 clearly violated Americans' sense of territorial differentiation' (p. 634), while the post-9/11 explosion in filmic representations of superheroes, such as Captain America, articulate American exceptionalism - a particularly American geopolitical vision and sense of self (Dittmer 2011 , p. 114). The impact of the crisis materialized in various forms of banal nationalism, 
for example purchases of American flags skyrocketed after 9/11 (Bratta 2009). At the same time the perception of the nation as a community gained credence.

Although most Americans considered the terrorist attacks against the United States on September 11, 2001, to be 'the death of comedy' (Kuipers 2005; see also Kuipers 2002), the amount of 9/11-related humor all around the media has been extensive. It was not a surprise that the American digital media company and news satire organization The Onion started writing sarcastic stories about the subject asking the reader to question and then to judge the hegemonic framework, the dualism of Good versus Evil (Warner 2008). In social media 9/11 jokes have received an extensive amount of criticism, which usually is targeted at how laughing at serious matters goes beyond decorum. In addition, criticism was also voiced, either directly or indirectly, over how 9/11 jokes are at odds with American values. Many of the conventional 9/11 jokes are relatively non-political or their politicality is implicit. And yet there is still an extensive amount of jokes in which the tragedy of 9/11 is used to make fun of Islamic culture and society. In fact, according to Kuipers (2002) 'the joke cycle about bin Laden and the attack on the World Trade Center is the first cycle of Internet disaster jokes' (p. 450). Regardless of criticism, the social media was quickly full of corny jokes such as:

Q: What's bin Laden's favorite football team?

A: The New York Jets

Q: What should have tipped off the ticket sellers?

A: When the terrorists asked if there was anything cheaper than one-way.

Q: What's the difference between science and religion?

A: Science flies you to the moon. Religion flies you into buildings.

The event of 9/11 was reported, and also later memorialized, through several iconic camcorder recordings of two planes crashing into the high towers of the World Trade Center. This is part of what I would call as the 'entertainmentalization of crisis'. Visual material is likely the most effective communicative route for making events seem 
emotionally loaded (e.g. humorous) and thus 9/11 was an easy target for joking, as visuality is a dominant aspect of American culture (Kuipers 2005). As discussed earlier in this paper, the media has a major influence on how the emotions attached to crisis events become processed by individuals, communities as well as nations. The media has its informative and educative function, but above all - especially in the case of the American media - it works as a source of entertainment, no matter what and how serious the content of the presented matter is. It has been argued, and criticized, that the American media 'expressed their sense that U.S. culture would change forever after the attacks on the World Trade Center and the Pentagon' while only a week later recommended the 'routine flow of commercially sponsored entertainment programming' (Spigel 2004, p. 235).

No matter how 'visual' the tragedy of 9/11 was, in American films it has been a relatively rare topic for humor. One of the exceptions was Sacha Baron Cohen's The Dictator (2012), a film feasting on stereotypes of Islamic culture, society and politics, at the same time making fun of Western society and the system of American foreign policy especially the Global War on Terrorism. The increased aggression and hatred towards anyone who appeared to be a 'terrorist that followed 9/11' (see Bratta 2009, p. 232) is satirized in the film, for example in a scene in which the star of the film, the fictitious Middle Eastern dictator Aladeen, and his fellow, the head nuclear scientist Nadal, take a helicopter ride over New York with two American tourists aboard. Aladeen and Nadal have a tempestuous discussion, in 'Arabic', over how Aladeen had crashed his Porsche 911 (pronounced in the film as 'nine/eleven') and how he planned to buy a new Porsche, '9/11, 2012'. After this the subject of the discussion changes to how they would like to see some of the Manhattan sights, such as the Empire State Building and Yankee Stadium and also see the fireworks over the Statue of Liberty, with Aladeen imitating load explosions, giving high fives to Nadal and then an evil smirk towards their American fellow travelers. The sequence ends when Nadal asks Aladeen about his back problems and Aladeen shows him his self-made back brace, which looks more like the explosive belt of a suicide bomber, after which they start demonstrating their developed English skills by counting down from five. When they get to zero, the American tourists start to scream and Aladeen and Nadal find themselves arrested. In IMDb film reviews this scene was interpreted as an example of the 
multidimensionality and even educative function of Baron Cohen's political sarcasm, targeted at the hypocrisy of American nationalism (Ridanpää 2012).

The event of 9/11 caused a national crisis, but there are also people for whom the disaster was an embodied crisis that was experienced and re-lived even years after the actual event. In similar manner to how it works as a coping strategy for cancer survivors, for example, in the case of 9/11 humor was used as a holistic, noninvasive strategy to 'heal' both survivor-clients and those who experienced the event (Pasquali 2003). The benefit of using humor during an event of crisis is often associated with its levity and relieving effects (Liu and Fraustino 2014). In crisis situations gallows humor and dark humor work as a cognitive and behavioral coping strategy in reaction to stressful events (Maxwell 2003). In psychological studies it has been underscored how in times of tragedy and crisis, humor functions as a technique for neutralizing emotionally charged areas and by that means provides hope (Simon 1988).

In the case of $9 / 11$, healing the survivors as well as mourning the victims was also important from the viewpoint of re-establishing American national self-esteem. Humor was thus a coping strategy not only for particular individuals but for the entire nation. On the other hand, Kuipers $(2005$, p.70) has argued that 'these jokes cannot be understood as a means of coping with grief and suffering. Rather, they are a comment on the serious and mournful tone of public discourse and media culture surrounding the events of 9/11, and a way for jokesters, for a variety of reasons, to separate themselves from that obligatory response'. No matter whether we understand the impact of 9/11 humor from an affirmative or destructive point of view, in this case humor had a major role in terms of offering (American) people new perspectives to understand the global geopolitical order. Humor produces geopolitical imaginations (see Dittmer 2013), and 9/11 and all the media discourses around it made a huge impact in terms of how American people reflected on their nationalist feelings and emotions within the wider geopolitical frame. 


\section{Global geopolitics and the Mohammed cartoons controversy}

Globalization is an economic, political, social and cultural process that has been going on for several centuries. 'Borderless world' has been one of the key terms around which the discussion over globalizing development has been recently conceptualized. Although global processes such as environmental change, migration and international trade illustrate how interaction and interdependence between different places around the world has increased, it is still argued that borders, especially national ones, direct the practices and forms of international systems (Diener and Hagen 2009). International crises, in their various forms, usually happen locally, while their consequences are discussed on the national and global level. The event discussed here, the Mohammed cartoon controversy, started as a partly local, partly national event that quickly escalated into a global geopolitical crisis with massive consequences across all scalar boundaries.

The Mohammed carton controversy started on September 30, 2005, when the Danish newspaper Jyllands-Posten published 12 Islam-themed satirical cartoons, some depicting Mohammed's face, a strictly forbidden act within Islamic culture. The visual representations of the sacrosanct Prophet first caused general indignation within the Islamic world and then boycotts of Danish products, the closing of embassies, violent mass demonstrations and later suicide bomb attacks, leaving many casualties and injured citizens. The cartoon crisis rapidly turned into a political face-off in which international organizations and national governments had to 'take sides'. The governments of 'Islamic countries' launched forceful and aggressive criticism against Jyllands-Posten, while practically all the countries of Western Europe defended the value of freedom of speech (for a more detailed discussion, see Ridanpää 2009). Finland was actually the only Western country in which the publishing of the Mohammed cartoons was condemned by the political leaders of the country.

The fact that the publishing of the Mohammed cartoons was condemned in Finland is particularly interesting since Scandinavian countries have often been labeled as being particularly atheistic, which has been used to explain the region's long tradition of humorous cartoons touching on religion; at the same token it is underscored how 
fundamentalist Christians are marginalized in Scandinavia (Davies 2008, pp. 4-5). The political leadership of Finland apologized to Islamic countries for the cartoons being published, which led to another event at the local level: the comical dismissal of the editor of a minor local culture journal in northern Finland, an ironic episode that was reported all across the world in major news outlets (Ridanpää 2009). This episode exemplifies how 'serious becoming humorous' and 'humorous becoming serious' are social processes that take place and happen not only at various spatial scales, but between them, in an interscalar manner.

What makes the Mohammed cartoon controversy an interesting example of the connections between global crisis and humor is that it demonstrated how humor can also function as an impetus that pushes crisis events into action. Cartoonists who work as employees in news agencies are an example of humorists who are actively involved with political issues. However, it is a commonly held view that cartoonists are merely passive observers of political conditions - who have 'a vague understanding of geopolitics on the popular level' (Berg 2003, p. 117) but who at the same time do not take an active part in political discussions by any means. Cartoonists are considered 'outsiders' within the journalistic community, which on the other hand enables them to use political satire in a way that is impossible for journalists (Dodds 1998, p. 174). It has been argued that humor, especially vulgar humor, reduces 'complex politics to the most basic and crass condition possible' (Thorogood 2016, p. 215). Especially in the case of cartoons, it has been emphasized how visuality makes it easier to comprehend and conceptualize complex geopolitical processes (Dodds 2010; Hammett 2011). On the other hand, it has also been argued that in many cases cartoons are politically ambiguous and complex: The paradoxical nature of climate change discourse, for example, can be illustrated by dissecting the ambiguities in political cartoons concerning the topic (Manzo 2012). Whereas journalists typically use irony as a rhetoric device to avoid being seen as naïve (Kunelius 2006, p. 680), cartoonists use irony in a more goal-oriented manner, with the benefit of being 'safe' from any serious consequences. However, as the Mohammed cartoon controversy demonstrated, humor can also trigger events that have far-reaching and serious global consequences. 
Irony usually has a 'target', also called its 'victim' (Hutcheon 1994, p. 15). It is characteristic of irony and especially of sarcasm that it is regularly used as a weapon, as a form of verbal aggression (Haiman 1998, p. 20). The Jyllands-Posten Mohammed cartoons are an example of victimizing humor, especially the example in which the Prophet Mohammed was depicted with a bomb in his turban. In order to get noticed, cartoon caricatures are often provocative in a goal-oriented manner, purposely simplifying, repeating and exaggerating their (geo)political messages (Dodds 2010). Cartoon caricatures have specific 'capacity to provoke a range of reactions ranging from laughter and amusement to offense and violence' (p. 117). The joke of a bomb in Mohammed's turban functioned as a weapon not because of the bomb but because the image was an undisguised representation of a modern Muslim stereotype, implying an unambiguously offensive argument. The image turned out to be the most provocative of the published drawings and demonstrated how satirical texts are oftentimes not even meant to be funny, but rather used as politically aggressive tools which function as weapons. Irony is a crafty weapon, since - as Katharina Barbe $(1995$, p. 89) argues - it gives speakers an opportunity to be aggressive in a seemingly un-aggressive way, which also indicates how irony functions as a means of keeping 'conflict at bay'. This is also true with respect to what Barbe sees as the facesaving nature of irony: 'When speakers attack directly, they in turn can be attacked, which leads to conflict. When employing irony, however, speakers are not as obviously aggressive and can thwart counter-attacks. Irony, therefore, turns conflict aside. A critical statement, once clothed in an inoffensive way, helps speakers and hearers to save face' ( $p$. 90). The same phenomenon has also been described as irony's capability to 'soften a threat' (Jorgensen 1996, p. 616).

The Mohammed cartoon controversy proved how humor can be 'risky business', legitimizing and undercutting a wide variety of interests in the service of a wide range of political positions. It has been also argued that, rather than clarifying the turbulent situation, the way in which the (Western) media portrayed the episode as a clash between free speech and religious sensitivities contributed to further confusion (Hussain 2007). On the other hand, in the Western media the angry reactions of the Islamic world, and Muslims' inability to 'take a joke', were made to appear not only drastically serious but also somewhat amusing and ironic, regardless of the unquestionably serious nature of the 
controversy (Ridanpää 2012). This is also connected to the claim that irony is a Western worldview (Muecke 1969). The images from a mass demonstration in Regents Park Mosque in London on February 3, 2006, organized by Muslim protesters against the publication of the Mohammed cartoons, were seen around the world, and despite the serious nature of the event, some ironic features were highlighted too. For example, criticizing the value of freedom of speech through swearing, with placards insisting 'FREEDOM OF EXPRESSION GO TO HELL!!', likely made many (Western) audiences laugh rather than be alarmed by the situation (Figure 1). In fact, the contradiction that comes from the seriousness of the event and those comical nuances involved makes the whole situation highly ironic.

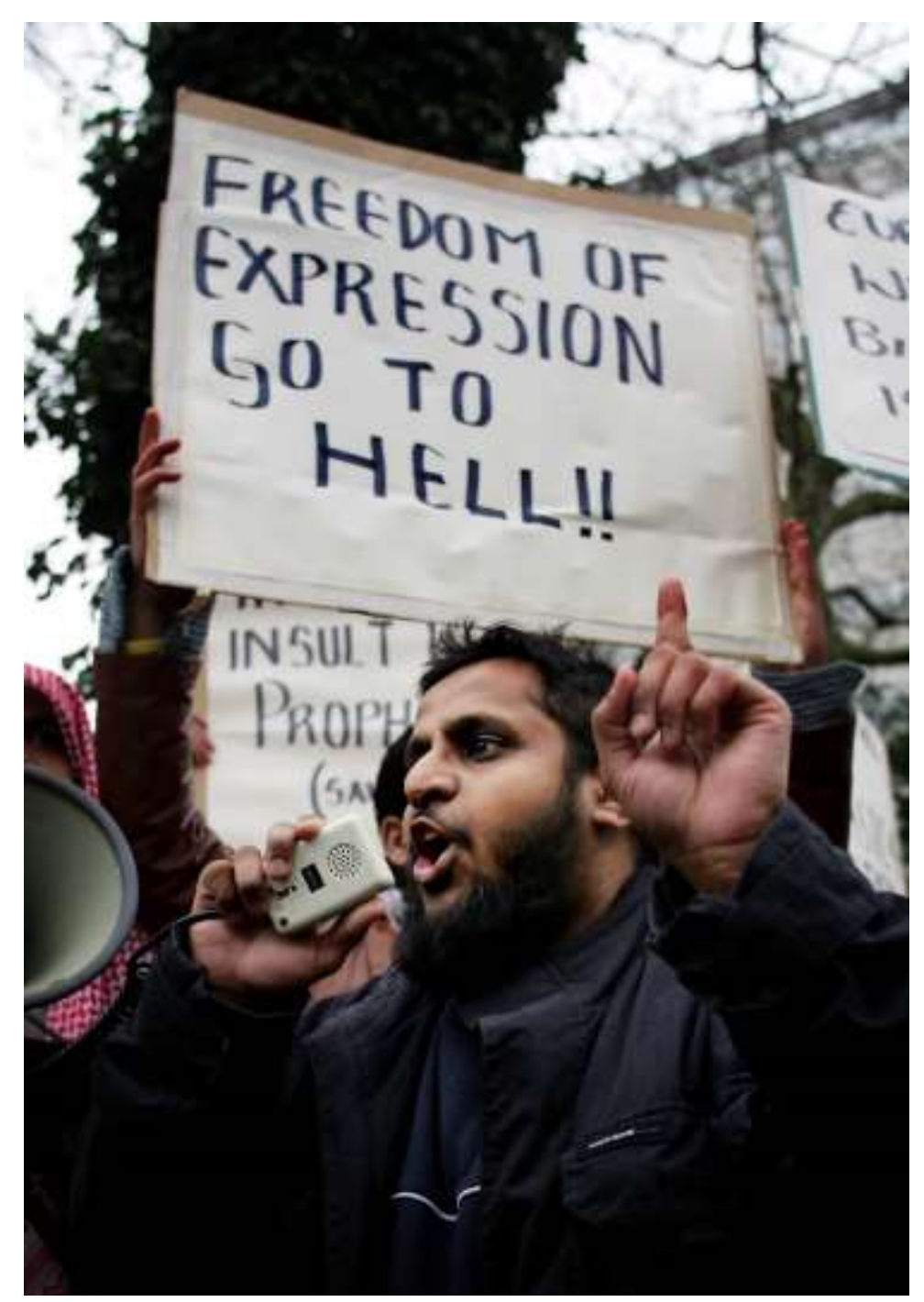

Figure 1. Muslim protesters at Regents Park Mosque holding placards protesting the Mohammed cartoons. Photograph by Timothy Allen on February 3, 2006; published by permission of Timothy Allen. 
The anger towards cartoons published in a Danish daily broadsheet newspaper changed quickly into anger towards Danish society and after a few days, American, British and French flags were burnt as well. In subsequent demonstrations the threatening messages of protest placards were mostly targeted at American geopolitical strategies and actions. The Mohammed cartoon controversy was followed by several other related events across the globe, of which probably the most notable was the attack on the French satirical weekly newspaper Charlie Hebdo. The magazine had a long history of satirizing the Prophet Mohammed and also of being a target of violent attacks. On January 7, 2015, the magazine's office was attacked by two gunmen who opened fire and killed 12 people. Hutcheon characterizes the nature of irony by how it 'may play on the edge, but it can also force people to the edge, and sometimes over it' (Hutcheon 1994, p. 43), and this was exactly what happened when the sacrosanct issue of parodying Mohammed was broached. Depicting Mohammed's face crossed the boundary of tolerance, and instead of making fun of a crisis, it produced one.

\section{Conclusions}

'We should not assume the effects of humour from the content of humour' (Dittmer 2013, p. 511; emphasis original).

As illustrated in this paper, humor is connected to events of crisis, and to the world of politics in general, in multiple ways. According to classic superiority theory, laughter is an outcome of the feeling of being superior to the object of the joke, from which it follows that laughter is often 'ignorant' or 'hostile' (Bergson 1911; Feinberg 1978). As is well known, humor has long been used as a weapon and as a tool for othering in various sociospatial circumstances. In the case of ethnic and sexist humor the objects of laughter are constantly living under crisis and this requires a substantial, if not insurmountable, amount of work to get people to realize the seriousness and offensiveness of the situation. On the other hand, humor contains an 'emancipatory power' and healing effect, and thus in events of crisis it can be used to help with handling sensitive and delicate issues. As mentioned earlier in this paper humor functions as a technique for neutralizing 
emotionally charged areas and for providing hope. It has been emphasized how humor, as a cultural institution, has a universal role of ensuring conformity and maintenance of social order (Billig 2005, pp. 201-202), functioning as a route or method to deal with strange, difficult and sensitive issues, to alleviate a fear of the unknown and the uncontrollable.

It is essential to note the importance of the joke-teller's own position and connection to the crisis event in question. While joking can be used for therapeutic purposes by the victims, it is highly problematic if the appreciator of the joke is an outsider and does not personally suffer from the crisis in question (Kuipers 2005, p. 71). In addition, understanding humor is personal and, especially in the case of irony, no matter how relieving or emancipatory, the point can easily be missed or misunderstood by the audience. Although in the case of the Mohammed cartoons controversy the question was not about misunderstanding the humor, since the cartoons were originally planned to provoke Danish Muslim communities, it still proved how humor can function also as an impetus to a series of serious crises events. As Dittmer argues, we should not assume the effects of humor from its content. Crisis is first and foremost a condition of 'unlaughter' (see Dodds and Kirby 2013), but through entertainmentalization people have come to love crisis. Being entertained by horrifying incidents has a long history, yet through (social) media crisis events have come to be a part of how people conceive of themselves as human beings, neighbors and state or global citizens in novel ways.

Crisis events take place on various scales, but their origins, context and consequences are often connected to other scales. 'Regional' is typically approached as a scale between local and national and especially as a spatial component of which nations consist. As in the case of Finland and Sámi people, connecting regional stereotypes with ethnic humor produces regional separation, at the same time serving nationalist political interests.

Correspondingly, the seriousness of humor, as in the cases of 9/11 or the Mohammed cartoon controversy, becomes realized and materialized only after the scalar contexts of crisis events have extended to new levels. In this paper sexist humor has been used as an example of how crisis events take place at the scale of the body, but to be precise, in most cases crisis events also cause emotions, such as sorrow, hatred, guilt, love (of country), and several other embodied reactions. To sum up, crises events and the humor associated with 
them thus represent sociopolitical impacts that in several manners (re-)produce not only interaction between the scales, but inter-scalarity itself.

\section{References}

Appleton, L. (2002). Distillations of something larger: the local scale and American national identity. cultural geographies, 9(4), 421-447.

Austin, L., Fisher Liu, B., \& Jin, Y. (2012). How audiences seek out crisis information:

Exploring the social-mediated crisis communication model. Journal of Applied Communication Research, 40(2), 188-207.

Barbe, K. (1995). Irony in Context. Amsterdam: John Benjamins Publishing Company.

Bemiller, M. L., \& Schneider, R. Z. (2010). It's not just a joke. Sociological Spectrum, 30(4), 459-479.

Beresford, M. (2018). Attitude Magazine slammed over jokes about Parkland School shooting. PinkNews 24th February 2018.

https://www.pinknews.co.uk/2018/02/24/attitude-magazine-slammed-over-jokes-aboutparkland-school-shooting/.

Berg, E. (2003). Some unintended consequences of geopolitical reasoning in post-Soviet Estonia: Texts and policy streams, maps and cartoons. Geopolitics, 8(1), 101-120.

Bergson, H. (1911). Laughter: An essay on the meaning of the comic. New York: MacMillan.

Billig, M. (1995). Banal Nationalism. London: Sage Publications.

Billig, M. (2005). Laughter and Ridicule. Towards a Social Critique of Humour. London: Sage. 
Bratta, P. M. (2009). Flag Display Post-9/11: A Discourse on American Nationalism. The Journal of American Culture, 32(3), 232-243.

Brenner, N. (2001). The limits to scale? Methodological reflections on scalar structuration. Progress in human geography, 25(4), 591-614.

Brubaker, R. (1996). Nationalism Reframed: Nationhood and the National Question in the New Europe. Cambridge \& New York: Cambridge University Press.

Burns, R., \& Crawford, C. (1999). School shootings, the media, and public fear: Ingredientsfor a moral panic. Crime, Law and Social Change, 32(2), 147-168.

Clark, J. (2017). Covering up Disfigurement and Laughing it Off: Reinforcing Inequality in Breast Cancer Support Groups. Sociological Inquiry, 87(1), 27-48.

Clark, T. (1988). The concept of a marketing crisis. Journal of the Academy of Marketing Science, 16(2), 43-48.

Davies, C. (1990). Ethnic humor around the world: A comparative analysis. Indiana: Indiana University Press.

Davies, C. (2008). The Danish cartoons, the Muslims and the new battle of Jutland. Humor, $21(1), 2-7$.

Davison, P. (2012). The Language of Internet Memes. In, M. Mandiberg (Ed.), The Social Media Reader (pp. 120-134). New York: New York University Press.

Delaney, D., \& Leitner, H. (1997). The political construction of scale. Political geography, 16(2), 93-97. 
Diener, A. C., \& Hagen, J. (2009). Theorizing borders in a 'borderless world': globalization, territory and identity. Geography Compass, 3(3), 1196-1216.

Dittmer, J. (2005). Captain America's Empire: Reflections on Identity, Popular Culture, and Post-9/11 Geopolitics. Annals of the Association of American Geographers, 95(3), 626-643.

Dittmer, J. (2011). American exceptionalism, visual effects, and the post-9/11 cinematic superhero boom. Environment and Planning D: Society and Space, 29(1), 114-130.

Dittmer, J. (2013). Humour at the model United Nations: the role of laughter in constituting geopolitical assemblages. Geopolitics, 18(3), 493-513.

Dodds, K. (1998). Enframing Bosnia: the geopolitical iconography of Steve Bell. In, S. Dalby S \& G. Ó. Tuathail (Eds.), Rethinking Geopolitics (pp. 170-197). Londres: Routledge.

Dodds, K. (2010). Popular Geopolitics and Cartoons: Representing Power Relations, repitition and Resistance. Critical African Studies, 2(4), 113-131.

Dodds, K. \& Kirby, P. (2013). It's not a laughing matter: Critical geopolitics, humour and unlaughter. Geopolitics, 18(1), 45-59.

Dyck, I. (2005). Feminist geography, the 'everyday', and local-global relations: hidden spaces of place-making. The Canadian Geographer/Le Géographe canadien, 49(3), 233243.

Eriksson, M. (2016). Managing collective trauma on social media: the role of Twitter after the 2011 Norway attacks. Media, Culture \& Society, 38(3), 365-380.

Escobar, A. (2007). The 'ontological turn'in social theory. A commentary on 'Human geography without scale', by Sallie Marston, John Paul Jones II and Keith Woodward. Transactions of the Institute of British Geographers, 32(1), 106-111. 
Feinberg, L. (1978). The Secret of Humor. Amsterdam: Rodopi.

Gough, J. (2010). Workers' strategies to secure jobs, their uses of scale, and competing economic moralities: Rethinking the 'geography of justice'. Political Geography, 29(3), 130139.

Grow, K. (2017). Stop Making Mass Murder a Meme: 'Thoughts and prayers' aren't enough - but sarcastic and outraged reactions to them aren't much better. Rolling Stone 15th February 2018. https://www.rollingstone.com/culture/stop-making-mass-murder-a-memew516822.

Haiman, J. (1998). Talk is cheap: Sarcasm, alienation, and the evolution of language. Oxford: Oxford University Press.

Halpern, H. A. (1973). Crisis theory: A definitional study. Community Mental Health Journal, 9(4), 342-349.

Hammett, D. (2011). Resistance, power and geopolitics in Zimbabwe. Area, 43(2), $202-210$.

Holton, R. J. (1987). The idea of crisis in modern society. British Journal of Sociology, 38(4), 502-520.

Howes, M. (2000). 'Goodbye Ireland I'm going to Gort': Geography, Scale, and Narrating the Nation. In D. Attridge \& M. Howes (Eds.), Semicolonial Joyce (pp. 58-77). Cambridge: Cambridge University Press.

Howitt, R. (2002). Scale and the other: Levinas and geography. Geoforum, 33(3), 299-313.

Hussain, A. J. (2007). The media's role in a clash of misconceptions: The case of the Danish Muhammad cartoons. Harvard International Journal of Press/Politics, 12(4), 112-130.

Hutcheon, L. (1994). Irony's edge: the theory and politics of irony. London: Routledge. 
Johnson, C., \& Coleman, A. (2012). The internal other: Exploring the dialectical relationship between regional exclusion and the construction of national identity. Annals of the Association of American geographers, 102(4), 863-880.

Jonas, A. E. (2006). Pro scale: further reflections on the 'scale debate'in human geography. Transactions of the Institute of British Geographers, 31(3), 399-406.

Jones, M. (2009). Phase space: geography, relational thinking, and beyond. Progress in Human Geography, 33(4), 487-506.

Jones, R., \& Desforges, L. (2003). Localities and the reproduction of Welsh nationalism. Political Geography, 22(3), 271-292.

Jorgensen, J. (1996). The functions of sarcastic irony in speech. Journal of Pragmatics, 26(5), 613-634.

Kotthoff, H. (2006). Gender and humor: The state of the art. Journal of pragmatics, 38(1), 425.

Kuipers, G. (2002). Media culture and internet disaster jokes: Bin Laden and the attack on the World Trade Center. European Journal of Cultural Studies, 5(4), 450-470.

Kuipers, G. (2005). "Where was King Kong when we needed him?" Public discourse, digital disaster jokes, and the functions of laughter after 9/11. The Journal of American Culture, 28(1), 70-84.

Kuipers, G. (2008). The sociology of humor. In V. Raskin (Ed.), The primer of humor research (pp. 361-398). Berlin: Mounton de Gruyter.

Kuipers, G. (2009). Humor styles and symbolic boundaries. Journal of Literary Theory, 3(2), 219-239. 
Kunelius, R. (2006). Good Journalism: On the Evaluation Criteria of Some Interested and Experienced Actors. Journalism Studies, 7(5), 671-690.

Lefebvre, H. D. (1991). The production of space. Blackwell: Oxford.

Lehtola, V.-P. (1997). Rajamaan identiteetti: lappilaisuuden rakentuminen 1920-ja 1930luvun

kirjallisuudessa. Helsinki: Suomalaisen kirjallisuuden seura.

Lehtola, V.-P. (2012). Saamelaiset suomalaiset: kohtaamisia 1896-1953. Helsinki: Suomalaisen Kirjallisuuden Seura.

Little, D. (2002). American orientalism: the United States and the Middle East since 1945. Chapel Hill, NC: University of North Carolina Press.

Liu, B. F., \& Fraustino, J. D. (2014). Beyond image repair: Suggestions for crisis communication theory development. Public Relations Review, 40(3), 543-546.

Lockyer, S., \& Pickering, M. (2008). You must be joking: The sociological critique of humour and comic media. Sociology Compass, 2(3), 808-820.

Manzo, K. (2012). Earthworks: the geopolitical visions of climate change cartoons. Political Geography, 31(8), 481-494.

Marston, S. A. (2000). The social construction of scale. Progress in human geography, 24(2), 219-242.

Marston, S. A., Jones, J. P., \& Woodward, K. (2005). Human geography without scale. Transactions of the Institute of British Geographers, 30(4), 416-432. 
Maxwell, W. (2003). The use of gallows humor and dark humor during crisis situations. International journal of emergency mental health, 5(2), 93-98.

Muecke, D (1969). The Compass of Irony. London: Methuen.

Norrick, N.R. \& Chiaro, D. (eds.) (2009). Humor in Interaction. Amsterdam: John Benjamins B.V.

Nuorgam, P. \& Karhu, J. (2010). Saamelaiskäsityön (duodjin) oikeudellinen suoja osana saamelaiskulttuuria. In Kokko, K.T. (Ed.), Kysymyksiä saamelaisten oikeusasemasta (pp. 172184). Rovaniemi: Lapin yliopisto.

Oksanen, A., Räsänen, P., Nurmi, J., \& Lindström, K. (2010). This can't happen here! Community reactions to school shootings in Finland. Research on Finnish Society, 3(1), 1927.

Paasi, A. (2004). Place and region: looking through the prism of scale. Progress in human geography, 28(4), 536-546.

Paasi, A., \& Metzger, J. (2017). Foregrounding the region. Regional Studies, 51(1), 19-30.

Palmer, J. (1993). Taking Humour Seriously. London: Routledge.

Pasquali, E. A. (2003). Humor: An antidote for terrorism. Journal of Holistic Nursing, 21(4), 398-414.

Perks, L.G. (2010). Polysemic Scaffolding: Explicating Discursive Clashes in Chapelle's Show. Communication, Culture and Critique, 3(2), 270-289.

Pollio, David E. (1995). Use of humor in crisis intervention. Families in Society, 76(6), 376376. 
Prokkola, E. K., \& Ridanpää, J. (2015). Border guarding and the politics of the body: An examination of the Finnish border guard service. Gender, Place \& Culture, 22(10), 13741390.

Purcell, D., Brown, M. S., \& Gokmen, M. (2010). Achmed the dead terrorist and humor in popular geopolitics. GeoJournal, 75(4), 373-385.

Reavy, P. (2018). Sheriff vows 'zero tolerance' for school shooting 'jokes'. Deseret News $27^{\text {th }}$ February 2018. https://www.deseretnews.com/article/900011508/sheriff-vows-zerotolerance-for-school-shooting-jokes.html.

Ridanpää, J. (2009). Geopolitics of humour: The Muhammed cartoon and the Kaltio comic strip episode in Finland. Geopolitics, 14(4), 729-749.

Ridanpää, J. (2010). A masculinist northern wilderness and the emancipatory potential of literary irony. Gender, Place and Culture, 17(3), 319-335.

Ridanpää, J. (2012). The Media and the Irony of Politically Serious Situations: Consequences of the Muhammed Cartoons in Finland. Media, Culture \& Society, 34(2), 131-145.

Ridanpää, J. (2014a). 'Humour is Serious' as a Geopolitical Speech Act: IMDb Film Reviews of Sacha Baron Cohen's The Dictator. Geopolitics, 19(1), 140-160.

Ridanpää, J. (2014b). Seriously Serious Political Spaces of Humor. ACME, 13(3), 450-456.

Ridanpää, J. (2016). 'Singing acts' from the deep North: critical perspectives on northern exotics, contemporary ethnic music and language preservation in Sámi communities. Journal for Cultural Research, 20(1), 17-30.

Rose, G. (1993). Feminism \& geography: The limits of geographical knowledge. Minnesota: University of Minnesota Press. 
Said, E. W. (1978). Orientalism: Western Conceptions of the Orient. London: Routledge.

Sidaway, J. D. (2000). Postcolonial geographies: an exploratory essay. Progress in Human Geography, 24(4), 591-612.

Simon, J. M. (1988). Therapeutic humor: Who's fooling who?. Journal of psychosocial nursing and mental health services, 26(4), 8-9.

Solomos, J., Findlay, B., Jones, S., \& Gilroy, P. (1982). The organic crisis of British capitalism and race: the experience of the seventies. In P. Gilroy/Center for Contemporary Cultural Studies (Eds.). The Empire Strikes Back. Race and Racism in 70s Britain (pp. 7-43). London: Hutchinson.

Spigel, L. (2004). Entertainment wars: Television culture after 9/11. American Quarterly, $56(2), 235-270$.

Terrion, J. L., \& Ashforth, B. E. (2002). From 'I'to 'we': The role of putdown humor and identity in the development of a temporary group. Human Relations, 55(1), 55-88.

Thomae, M., \& Pina, A. (2015). Sexist humor and social identity: The role of sexist humor in men's in-group cohesion, sexual harassment, rape proclivity, and victim blame. Humor, 28(2), 187-204.

Thorogood, J. (2016). Satire and geopolitics: Vulgarity, ambiguity and the body grotesque in South Park. Geopolitics, 21(1), 215-235.

Tuulentie, S. (2001). Meidän vähemmistömme: Valtaväestön retoriikat saamelaisten oikeuksista käydyissä keskusteluissa. Helsinki: Hakapaino.

Virkkula, S. (2000). Lappi kirjallisuudessa Barokista. Oulu: Oulun yliopisto. 
Warner, J. (2008). Tyranny of the dichotomy: Prophetic dualism, irony, and The Onion. The Electronic Journal of Communication, 18(2-4).

Weaver, T. (2017). Urban crisis: The genealogy of a concept. Urban Studies, 54(9), 20392055.

Xiao, Y., Cauberghe, V., \& Hudders, L. (2017). Humour as a double-edged sword in response to crises versus rumours: The effectiveness of humorously framed crisis response messages on social media. Journal of Contingencies and Crisis Management, https://doi.org/10.1111/1468-5973.12188. 